\title{
Roy Porter (1946-2002)
}

Lastimavelmente quase um anônimo para os psiquiatras brasileiros, Roy Sidney Porter, historiador que nos últimos vinte anos se tornou uma das mais conceituadas figuras intelectuais do mundo, faleceu recentemente aos 55 anos de idade. ${ }^{1}$

Porter praticamente inventou o estudo acadêmico da história da "loucura" entre os historiadores e, em parceria com German Berrios, foi autor dos mais eruditos capítulos sobre a história da prática psiquiátrica. O próprio Berrios afirma que essa combinação entre o psiquiatra e o historiador (dedicado, ressalta) é a mais útil para o estudo da história da psiquiatria, cada um contrabalançando as possíveis idiossincrasias - variáveis sociais de um lado e excessos biológicos de outro. ${ }^{2}$

Aliás, um excelente exemplo de parceria entre os dois autores pode ser visto no excelente History of Clinical Psychiatry de 1995. Professor de História Social da Medicina de Londres e research Fellow no Wellcome Institute de 1993 a 2001, foi o autor e editor de mais de 200 livros e artigos científicos, e produtor de diversos programas históricos para o rádio e televisão britânica, o mais recente sobre o Renascimento.

Entre seus livros é possível destacar A social History of Madness (1996), um dos poucos traduzido para o português, The Greatest Benefit to Mankind: A medical History of humanity, (1997), Madness: A brief history (2002), Gout: the disease of top people (1974), The Faber Book of Madness (1993), The Cambridge Illustrated History of Medicine (1996), entre tantos outros.

Colecionou inúmeras honrarias entre elas Fellow da British Academy em 1994, Honorary Fellow do Royal College of Physicians e do Royal College of Psychiatrist. Foi editor de duas respeitáveis revistas acadêmicas, History of Sciencee cofundador com German Berrios do, History of Psychiatry.

A leitura de seus livros e artigos mostra que Porter entendia a história da medicina não como a história dos médicos, mas a história dos doentes e das sociedades.

Enquanto no Brasil a história da "loucura' é frequientemente associada a visões antipsiquiátricas, Roy Porter desenvolveu uma história da psiquiatria sem discutir modelos casuais, mas situando-se no meio da arte, da filosofia e do movimento científico de cada época, uma história do ponto de vista do paciente.

No início dos anos 80, ele iniciou com Bill Bynum diferentes seminários sobre a história da psiquiatria, dando origem ao que é possível chamar de a era pós-antipsiquiatria da historiografia psiquiátrica, que os autores publicam sobre o título de "The Anatomy of Madness". Profundo conhecedor e crítico da historiografia da psiquiatria de Szasz e Foucault baseada no confinamento, na exclusão e na fabricação da loucura, aponta seus excessos em várias situações. ${ }^{4-5}$

Nascido em Hitchin, em 31 de dezembro de 1946, estudou História no Christ's College em Cambridge, onde passou onze anos e posteriormente foi para o Churchill College. Apresentou sua tese de doutorado em 1977 sobre Geologia (The Making of Geology: Earth Science in Britain, 1660-1815).

Mudou-se para Londres em 1979, aí residindo até aposentar-se precocemente em 2001.

Recordo-me de ter visto com muita surpresa Roy Porter em Londres, pedalando alegremente sua bicicleta num frio tiritante. Soube mais tarde que esse era seu meio de transporte favorito, todo o tempo querendo afastar-se do esnobismo acadêmico e manter a imagem de um homem vindo da working-class. Após quatro casamentos e divórcios, seu último livro (Madness: A brief history) traz uma última dedicatória à Natsu Hattori sua derradeira companheira ("yes again, to the love of my life"). ${ }^{3}$

Roy Porter foi encontrado morto em Hastings, Sussex, junto a sua bicicleta em três de março de 2002.

Taki Athanássios Cordas

Ambulatório de Bulimia e Transtornos Alimentares (AMBULIN) do Instituto de Psiquiatria do Hospital das Clínicas FMUSP e Departamento de Psiquiatria da FMUSP

\section{Referências}

1. Bynum WF. Roy Porter, Profilic Scholar whose books and broadcasts revealed the medical and social history of England. The Guardian; 2002; March 5:20.

2. Berrios GE. Historiography of mental systems and disease. History of psychiatry; 1994. p. 175-90.

3. Porter R. Madness. In: A buef history. Oxford: Oxford Univ Press; 2002.

4. Berrios G, Porter R. A history of clinical psyquiatry. In: The origin and history of psychiatric disorders. Londres: Athlone Press; 1995.

5. Jones C, Porter R. Reassessing foucault: power, medicine and the body (studies in the social history of medicine). London: Routledge; 1998. 